\title{
CHRONIC INFLAMMATORY DEMYELINATING POLYRADICULOPATHY
}

\author{
Noer Hassianni Mercy L. Tobing*, Agus Yudha Wijaya*, Christina Aritonang*, Yoyok Hendro \\ Bijaksono* \\ *Departemen Ilmu Penyakit Saraf \\ Fakultas Kedokteran Universitas Kristen Indonesia
}

\begin{abstract}
Abstrak
Chornic inflammatory demyelinating polyradiculoneuropathy (CIDP) merupakan penyakit immune-mediated neuropati (neuropati karena gangguan imunologis), penyakit yang jarang, langka dan bentuknya bermacam-macam (heterogen), tetapi dapat diobati. Selama abad 20 pengenalan CIDP masih terbatas, sehingga sebutan nama penyakit berbeda-beda. Deskripsi klinis dan histopatologis sering bercampur dengan penyakit mirip seperti sindrom Guillain-Barre'. Untuk mendiagnosis penyakit CIDP perlu dilakukan pemeriksaan eletromiografi (EMG) menilai kecepatan hantar saraf dan merupakan pemeriksaan diagnostik pasti. Ultrasound saraf dan MRI dapat pula membantu dalam diagnosis.
\end{abstract}

CIDP terbagi dalam dua tipe yaitu tipikal CIDP dan varian atipikal CIDP. Varian atipikal CIDP dengan fenotipen berbeda menjadi tantangan dalam melakukan diagnosis.

Kata kunci : CIDP, Gangguan Imune Mediate yang didapat, Jarang, Kasus sulit, Terapi jamgka panjang

\begin{abstract}
Chornic inflammatory demyelinating polyradiculoneuropathy (CIDP) it is an disease of immune-mediated neuropathy (neuropathy due to immunological disorders), rare, the disease that can take many forms (heterogeneous), but treatable,. For much of 20th centuries the introduction of CIDP has been limited so that it is referred to under different disease names. Clinical and histopathologic descriptions are often confused with a disease-like appearance such as Guillain-Barre 'syndrome. To diagnose CIDP, it is necessary to perform an eletromyography (EMG) examination to assess the velocity of nerve conduction and this is an definite diagnostic test. Neural ultrasound and MRI can also help in diagnosis.

CIDP is divided into two types, namely typical CIDP and atypical variants of CIDP. Atypical variants of CIDP with different phenotypes present a diagnostic challenge.

Keywords : CIDP, Acquired Imune mediated disorder, Rare case, Difficulty case, Longterm treatment
\end{abstract}




\section{Pendahuluan}

Chronic Inflammatory Demyelinating Polyneuropathy (CIDP) adalah neuropati yang bersifat immune-mediated yang dapat mengakibatkan kelemahan motorik, ataxia, dan gangguan sensorik. Kasus ini merupakan kasus jarang pada bagian Neurologi. Prevalensi yang dilaporkan berkisar antara 0,67 - 13,3 kasus per 100.000 orang dan rentang kejadian yang dilaporkan sebanyak 0,15 - 10,6 kasus per 100.000 orang tiap tahunnya. Dalam studi epidemiologis menunjukkan paling banyak dialami oleh laki-laki dengan peningkatan insiden dan prevalensi meliputi usia. Untuk faktor risikonya sendiri masih belum diketahui secara pasti. ${ }^{1,2}$

CIDP adalah penyakit imunologis dan heterogen sehingga secara klinis sulit dibedakan dari poliradiculoneuropati lainnya seperti sindrom Guillain-Barre'. Diagnosis CIDP bisa sulit, terutama pada pasien yang tidak menunjukkan gangguan motorik dan sensorik secara progresif atau kekambuhan, dimana yang khas dari polineuropati umumnya melibatkan otot-otot proksimal. ${ }^{2}$

Kasus ini berbeda dengan polineuritis akut (Sindrom Guillain-Barre') pada CIDP sifatnya kambuh-kambuhan dan biasanya memiliki perburukan yang bertahap. Sebuah laporan (tahun 1929) menjelaskan kasus polineuropati yang berulang pada seorang pria berusia 45 tahun, membuktikkan gambaran klinis utama yaitu kelemahan pada bagian proksimal dan distal ekstremitas yang relatif simetris, hiporefleksia sampai arefleksia, juga mengalami gangguan sensoris. $^{3}$

CIDP adalah kondisi yang dapat diobati, karena itu penting menghindari penundaan diagnostik, tetapi kesalahan diagnosis CIDP sering terjadi. Menurut European Federation of Neurological Societies/Peripheral Nerve Society (EFNS/PNS) tahun 2010, diagnosis terhadap CIDP menjadi tantangan karena pada saraf terjadi proses demielinasi, ${ }^{4}$ Pada CIDP tidak selalu ditemukan kelainan elektrodiagnostik. ${ }^{5}$ Pada pasien ini, pencitraan saraf baik dilakukan dengan USG maupun MRI, yang dapat menunjukkan saraf median proksimal atau indikasi adanya pembesaran dari radix saraf, yang ditandai dengan polineuropati yang bersifat immunemediated. ${ }^{6}$

Pada pasien yang menunjukkan sedikit/tidak ada perbaikan, perlu dilakukan pemeriksaan spesifik yang berkaitan dengan mekanisme penyebab terjadi gangguan imunologis. Pemeriksaan imunologis yang 
dianjurkan adalah imunoglobulin G4 (IgG4), dimana ini adalah suatu tes antibodi yang melawan protein nodal dan paranodal. Pada penderita CIDP dapat diobati menggunakan imunoglobulin intravena/subkutan, kortikosteroid atau plasma exchange. Pasien dengan kelainan antibodi IgG4 mungkin tidak cukup dengan pengobatan CIDP standar, akan tetapi dapat menunjukkan peningkatan yang luar biasa dengan obat rituximab, antibodi anti-CD20 monoklonal yang menunjukkan jumlah sel B. ${ }^{7}$

CIDP mempunyai berbagai fenotipe klinis, dengan patogenesis berbeda dari semua varian CIDP atau penyakit yang mirip CIDP. Karena tidak adanya definisi secara pasti, laporan dari CIDP tipikal dan varian CIDP atipikal masih bervariasi dalam berbagai studi. Gambaran umum tentang fenotipe CIDP tipikal dan varian CIDP atipikal tersedia pada tabel 1 .

\section{Tabel 1. Gambaran umum CIDP tipikal dan atipikal ${ }^{8}$}

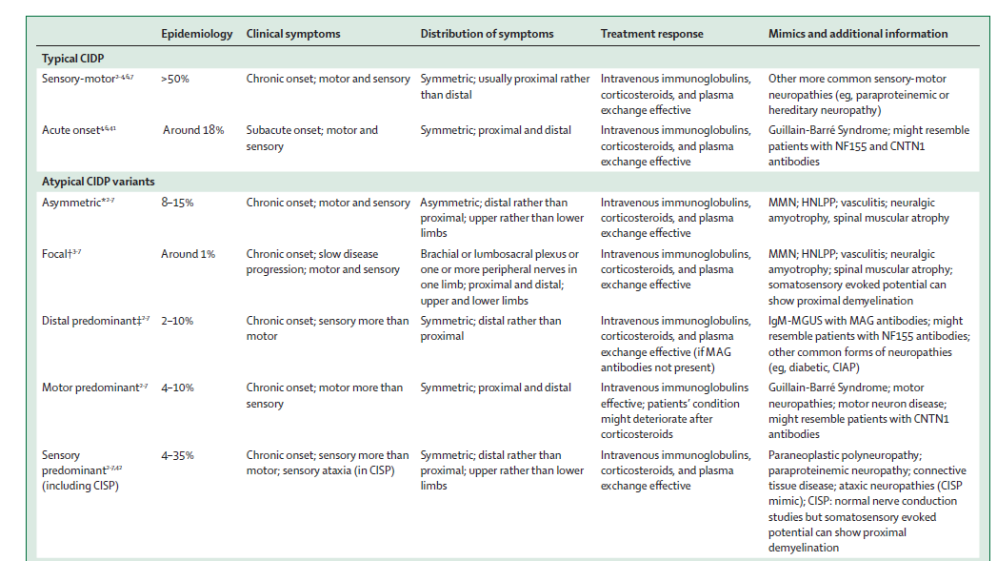

Tujuan:

Tulisan ini merupakan laporan kasus jarang, pada tulisan ini dilaporkan kejadian CIDP pada seorang wanita 59 tahun dengan pekerjaan sebagai ibu rumah tangga. 


\section{Laporan Kasus}

Seorang wanita usia 59 tahun datang dengan keluhan lemas pada keempat ekstremitas, terutama ekstremitas bawah pada bagian kanan, nyeri sendi, nyeri otot, nyeri dada dan kadang-kadang disertai sesak. Sejak 1 tahun yang lalu pasien sempat mengalami hal yang sama yaitu lemas pada kedua tungkai bawah dan keluhan yang dirasakan bertambah berat pada kekuatan motorik dan sensorik, nyeri pada sendi, otot, punggung, dada dan keempat ekstremitas. Pada pasien ini pernah dianggap sebagai menderita sindrom Guillian-Barre' (2 tahun yang lalu)disertai kelemahanan pada ekstremitas atas bagian kiri yang semakin bertambah berat (progresif). Pasien sempat diberikan obat imunoglobulin intravena dan kortikosteroid, setelah pengobatan pasien mengalami perbaikan.

$$
\text { Pada pemeriksaan neurologi }
$$
didapatkan kesadaran compos mentis, pada nervus kranialis teradapat gangguan visus oculi dextra, sistim motoriknya ditemukan tetraparese, kelemahan pada otot-otot proksimal, sensabilitas mengalami gangguan rasa raba pada kedua kaki dan refleks fisiologi mengalami penurunan kiri dan kanan.
Dilakukan pemeriksaan MRI otak dan tidak ditemukan kelainan.

MRI vertebralis hasil:
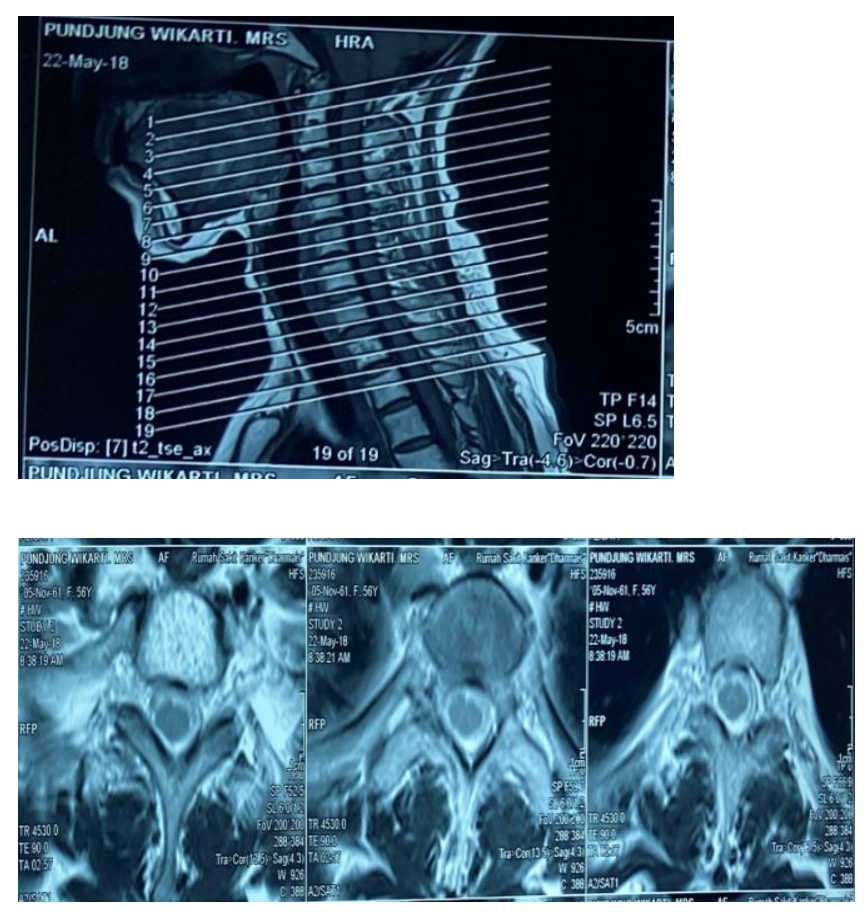

\section{Gambar 1. Pemeriksaan MRI tampak bone marrow replacement di TH 1}

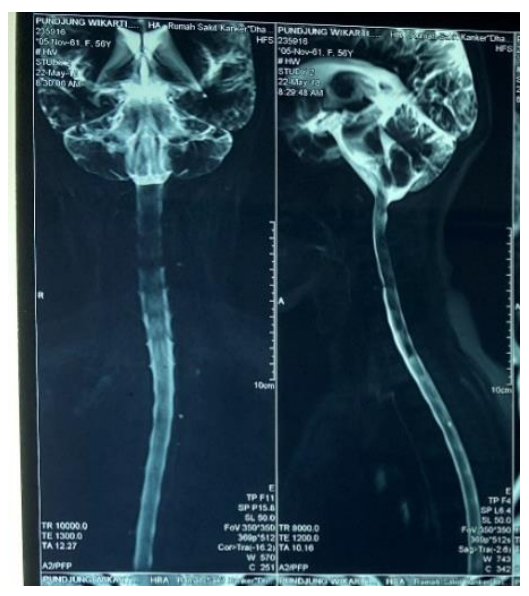



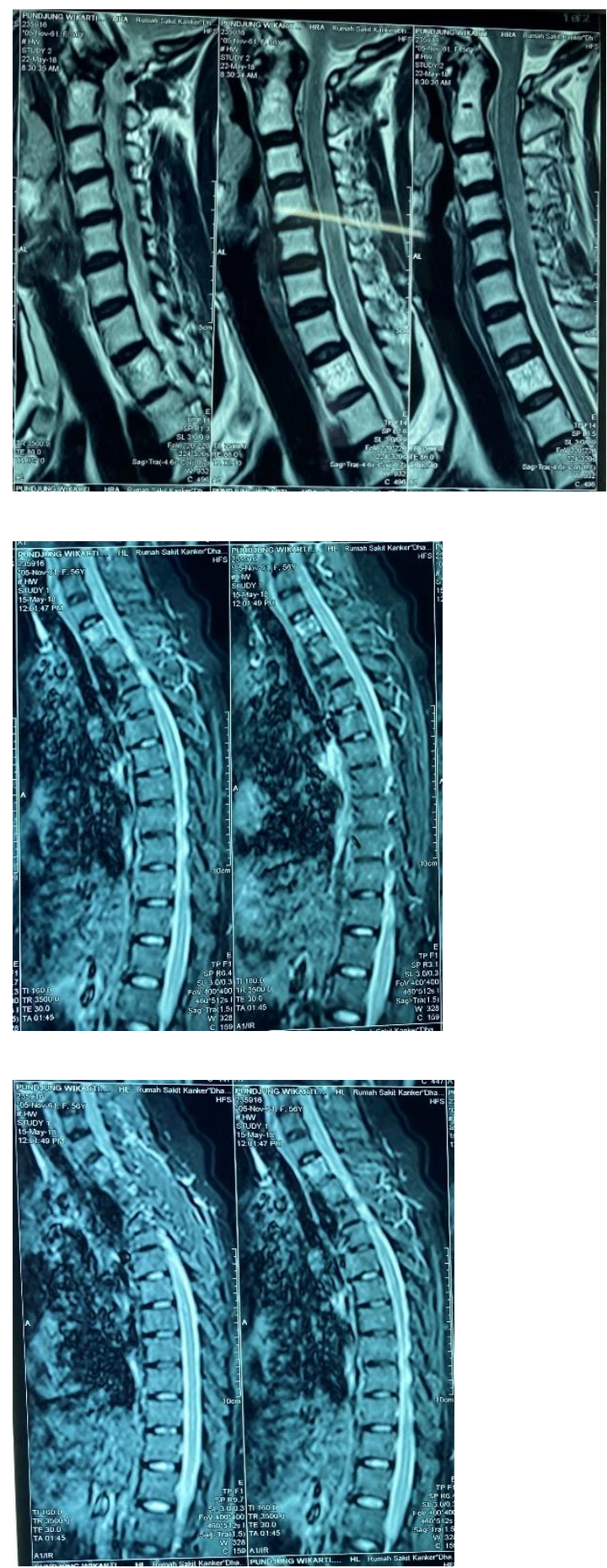

Gambar 2. Pemeriksaan MRI tampak contras posterior bulging disc pada C3-C4, C4-C5, C5-C6, L4-L5, L5-S1 dengan penekanan dan penyempitan ringan dan vertebra thoracalis scoliosis kanan.
Pada MRI vertebra cervico thoracal, kesan: whole spine baik, vertebra thoracalis scoliosis kanan, tidak tampak listesis, bone marrow replacement di thoracal 1 dengan suspect metastasis. Sentral posterior bulging disc C3-C4, C4-C5, C5-C6, L4-L5, L5-S1 dengan penekanan dan penyempitan ringan. Spinal canal facet artrosis di L4-L5 bilateral mild, canal stenosis di C3-C4, C4-C5, C5C6, L4-L5, L5-S1, neural foramen tidak menyempit, tidak dicurigai kompresi radiks, tidak ada lesi intra medular dan intrathecal,

Untuk hasil pemeriksaan Elektromiografi (EMG) pada kedua tungkai dan lengan kanan didapatkan : KHS sensorik N. Medianus, N. Ulnaris, dan N. Suralis normal, SNAP N. Suralis tidak muncul, Fwave N. Peroneus bilateral tidak muncul, KHS motorik N. Medianus, N. Ulnaris, N. Peroneus bilateral dan N. Tibialis bilateral normal : kesan sesuai dengan gambaran poliradiculoneuropati.

Pemeriksaan laboratorium gula darah sewaktu $135 \mathrm{mg} / \mathrm{dl}$, gula darah puasa 141 $\mathrm{mg} / \mathrm{dl}$, asam urat 3,4 $\mathrm{mg} / \mathrm{dl}$, dan pemeriksaan elektrolit dalam batas normal. 


\section{Diskusi}

Chronic inflammatory demyelinating
polyneuropati (CIDP) adalah suatu gangguan neurologis yang karakteristiknya kelemahan progresif dan gangguan fungsi motorik dan sensorik pada tungkai atas dan tungkai bawah. Gangguan ini disebabkan oleh kerusakan selubung mielin (selubung lemak yang membungkus dan melindungi sekeliling serat nervus) nervus perifer. Demielinasi nervus perifer menyebabkan kelemahan pada keempat ekstremitas yang berkembang secara progresif dan lebih berat sepanjang tahun. Untuk gejala khasnya pertama kali yang dirasakan sebagai tingling (kesemutan) atau rasa tumpul pada jari-jari kaki dan tangan. ${ }^{2}$

CIDP adalah suatu gangguan sistem imun. Khususnya, karena sistem imunologis kita tidak dapat mengenal sel-sel myelin nervus perifer dan menganggapnya sebagai agent asing. Kerusakan selubung terjadi saat sistem imun mencoba untuk membersihkan tubuh dari agent asing. Proteksi melawan respon-respon imun terhadap autoantigen adalah kunci untuk pemeliharaan selftolerance. Pada CIDP, self-tolerance mengalami kerusakan, dan terjadi autoreactive dari sel $\mathrm{T}$ dan sel $\mathrm{B}$, yang menjadi bagian normal imunitas, mengalami aktivasi sehingga menyebabkan kerusakan organ spesifik yang menjadi ciri khas penyakit-penyakit autoimun. ${ }^{8}$

Seperti sindrome Guillain-Barre', dimana terjadinya dipicu oleh pasca infeksi virus, akan tetapi hingga sekarang belum ada yang dapat menjelaskan apakah infeksi virus atau mikroba dapat secara langsung menyebabkan CIDP. CIDP berbeda dengan sindrom Guillain-Barre' pasca infeksi virus, gejala gejala CIDP baru timbul beberapa bulan kemudian. Pada sindrome GuillainBarre', pasca infeksi virus atau bakteri, gejala klinis timbul beberapa hari atau minggu. ${ }^{1}$

Pemeriksaan penunjang yang dapat dilakukan meliputi pencitraan MRI, MRI pada pasien ini ditemukan kecurigaan adanya metastasis pada torakal 1. Adanya bulging discus di C3-4, C4-5, C5-6, L4-5, L5-S1 dengan penyempitan kanal. Kanal facet artrosis di L4-5 bilateral. Mild canal stenosis di C3-4, C4-5, C5-6, L4-5, L5-S1. Kelainan pada vertebra2 ini, bisa juga menunjukkan kelainan 2 klinis pada kasus ini, tapi berbeda dengan CIDP, karena pada kasus ini ganguan klinis padapasien ini menunjukkan perburukan progresifyang sesuai dengan CIDP.

Hasil EMG kasus ini, terdapat KHS sensorik n. Medinus, n. Ulnaris, n. Suralis normal. SNAP n. Suralis tidak muncul, F wave n. Peroneus bilateral tidak muncul. Hasil EMG ini sesuai dengan CIDP

Dalam penanganan CIDP umumnya terapi yang diberikan meliputi kortikosteroid (mis. Prednisone), Plasmaphaeresis (plasma exchange) dan imunoglobulin intravena (IVIg) yang dapat diberikan tunggal atau kombinasi dengan obat immunosupresif lain. Pada dasarnya penanganan dan pengobatan CIDP dan sindrom GuillainBarre' sama. Penggunaan kortikosteroid seperti prednisone, dapat mempengararuhi 
respon sistem imun sehingga demielinasi yang terjadi berkurang. Umumnya pada CIDP bila terjadi perburukan dalam klinisnya (motorik, sensorik dan kelainan lainnya) dapat diberikan metilprednisolon $500 \mathrm{mg}$ per minggu dalam 3 bulan dan dosis ini dinilai kembali setiap 3 bulan dengan menaikkan atau menurunkan dosis 50 - 100 mg tergantung status klinisnya. Untuk meminimalisir resiko osteoporosis dapat juga tiap hari diberikan cholecalciferol 600 U dan kalsium karbonat 1500 mg. ${ }^{9}$

Pada kasus ini pasien mendapat pengobatan kortikosteroid dan IVIg, dengan pengobatan ini pasien mengalami perbaikan, sehingga tidak dilakukan plasmaferesis. Setelah 1 tahun kemudian pasien sering mengalami kelemahan motorik, gangguan sensorik dan rasa nyeri di berbagai bagian tubuh. Dengan pemberian kortikosteroid dan analgetik, keluhannya berkurang.

\section{Kesimpulan}

Chronic Inflammatory Demyelinating Polyneuropathy (CIDP) adalah neuropati yang bersifat immune-mediated yang dapat mengakibatkan kelemahan motorik, ataxia, gangguan sensorik dan gangguan otonom yang timbul secara signifikan, karena sistem imunologis tidak dapat mengenal sel-sel myelin nervus perifer dan menganggapnya sebagai agent asing.

CIDP berbeda dengan sindrom Guillain-Barre', pada CIDP gejala baru timbul beberapa bulan kemudian sedangkan pada sindrome Guillain-Barre', pasca infeksi virus atau bakteri, gejala timbul beberapa hari atau minggu. Oleh karena itu perlu mendiagnosis lebih awal pada kasus CIDP untuk mencegah kerusakan saraf perifer lebih lanjut.

Pemeriksaan penunjang yang dapat dilakukan meliputi elektromiografi (EMG) dan juga pencitraan MRI.

Pengobatan CIDP pada umumnya adalah pemberian kortikosteroid (mis. Metylprednisone), Plasmaphaeresis (plasma exchange) dan imunoglobulin intravena (IVIg) yang dapat diberikan tunggal atau kombinasi dengan obat immunosupresif lain. Pengobatan metilprednisolon sering harus diberikan dalam jangka panjang untuk menghindari terjadi remisi dan perburukan dari penayakit CIDP. 


\section{Daftar Pustaka}

1. Broers MC, Buncshoten C, Nieboer D, Lingsma HF, Jacobs, Incidence and Prevalence of Chronic Inflammatory Demyelinating Polyradiculopathy: a Systemic Review and Meta-Analysis, Neuroepidemiology 2019; 52: 161-72.

2. Mahdi-Rogers M, Hughes RAC. Epidemiology od Chronic Infalmmatory Neuropathies in Southeast England. Eur J Neurol 2014; 21: 28-33.

3. Harris W, Newcomb WD. A Case of Relapsing Interstitial Hypertropic Polyneuritis. Brain. 1929; 52: 108-116.

4. Van den Bergh PY, Hadden RD, Bouche $\mathrm{P}$, et al. EuropeanFederation of Neurological Societies/Peripheral Nerve Societyguideline on management of chronic inflammatory demyelinating polyradiculoneuropathy: report of a joint task force of the EuropeanFederation of Neurological Societies and the Peripheral NerveSociety - first revision. Eur J Neurol2010; 17: 356-63.

5. Allen JA, Lewis RA. CIDP diagnostic pitfalls and perception oftreatment benefit. Neurology 2015; 85: 498-504.

6. Goedee HS, Van Der Pol WL, Van Asseldonk JTH, et al. Diagnosticvalue of sonography in treatment-naive chronic inflammatoryneuropathies. Neurology 2017; 88: 143-51.

7. Kieseier BC, Mathey EK, Sommer C, Hartung HP.Immune-mediated neuropathies. Nat Rev Dis Primers 2018; 4: 31 .

8. Carina B., Bart C. J, Peter Y. K. V, David R. C, Pieter A. V, Progress in Diagnosis and Treatment of Chronic Inflammatory Demyelinating Polyradiculoneuropathy, Lancet Neural, Vol : 18, 2019.

9. Suraj. A. M, Praful K, Gareth J. P, Treatment of Chronic Inflammatory Demyelinating Polyneuropathy With Pulsed Oral Steroid, American Medical Association, Vol : 65, 2008.

10. Ted M. B, Chronic Inflammatory Demyelinating Polyradiculoneuropathy, History of Neurology : Seminal Citation, University of Virginia Department of Neurology, Vol : 61, 2004 